\title{
PENGARUH SISTEM AKUNTANSI DAN PENGENDALIAN INTERNAL TERHADAP PEMBERIAN KREDIT OLEH PT BANK OCBC NISP TBK KOTA BATAM
}

\author{
Syahril Effendi ${ }^{1}$, Baru Harahap ${ }^{2}$ \\ Universitas Putera Batam \\ email: syahril@puterabatam.ac.id
}

\begin{abstract}
This study aims to prove that the existence of partial and simultaneous influence of variables Accounting System $\left(X_{1}\right)$ and Internal Control $\left(X_{2}\right)$ of the variable Lending $(Y)$ at PT Bank OCBC NISP Tbk Batam. The analysis used in this study is Regression Analysis which has the aim to determine the regression coefficients besarknya which will show the influence of the independent variables on the dependent variable. The results of the $t$ test showed that variables Accounting System $\left(X_{1}\right)$ significantly affects Lending $(Y)$ with $T_{\text {count }}(7,469)>T_{\text {table }}(1.65521)$ with significant $=0.000<0.05$ and Internal Control $(X 2)$ significantly affects Lending $(Y)$ with $t_{\text {count }}(6,339)>T_{\text {table }}(1.65521)$ with significant $=$ $0.000<0.05$. F Test results showed that the Accounting System $\left(X_{1}\right)$ and Internal Control $\left(X_{2}\right)$ simultaneously influence on Lending $(Y)$ with $F_{\text {count }}(659.4509)>F_{\text {table }}(3.06)$ and significant $=0.000$ $<0.05$. Rated $R$ Square of 0.899 , showing the extent of the role or contribution of variables Accounting and Internal Control Systems is able to explain the variable Lending by $89.9 \%$, while $10.1 \%$ are influenced by factors that are not included in this study.
\end{abstract}

Keywords: Accounting Systems, Internal Control, and Lending

\section{PENDAHULUAN}

Perbankan merupakan lembaga keuangan yang berperan sebagai alat penggerak pertumbuhan dan pengerak ekonomi yang fungsinya tidak dapat dipisahkan dari pembangunan indonesia. Menurut Undang - Undang Republik Indonesia tentang Perbankan No. 7 Tahun 1992 sebagaimana telah disempurnakan dalam Undang - Undang No. 10 Tahun 1998, Bank adalah badan usaha yang menghimpun dana dari masyarakat dalam bentuk simpanan dan menyalurkan kepada masyarakat dalam bentuk kredit atau bentuk - bentuk lainnya dalam rangka meninggkatkan taraf hidup rakyat banyak.

Menurut Dendawijaya (2009: 14) Bank adalah suatu badan usaha yang tugas utamanya sebagai perantara keuangan (financial intermediaries), yang menyalurkan dana dari pihak yang berlebihan dana (idle fund surplus unit) kepada pihak yang membutuhkan dana atau kekurangan dana (deficit unit) pada waktu yang ditentukan.

Pemerintah mengarahkan pembangunan nasional khususnya dibidang ekonomi sebagai usaha mewujudkan tujuan pembangunan nasional yang merata dan dapat dinikmati oleh seluruh rakyat. Diantara berbagai kebijakan ekonomi yang dilaksanakan, bidang perbankan merupakan salah satu bidang yang mendapat perhatian pemerintah.

Sebagaimana diketahui, menurut Kasmir (2011:18) Undang - Undang tersebut diatas mengelompokan perbankan di Indonesia menjadi 2 kelompok yaitu

1. Bank Umum adalah Bank yang melaksanakan kegiatan usaha secara konvensional atau berdasarkan prinsip syariah yang dalam kegiatannya memberikan jasa lalu lintas pembayaran.

2. Bank Perkreditan Rakyat (BPR) adalah Bank yang melaksanakan kegiatan usaha secara konvensional atau berdasarkan prinsip syariah yang dalam kegiatannya tidak memberikan jasa lalu lintas pembayaran. 
Pada awalnya Bank dinyatakan sebagai tempat untuk para masyarakat menghimpun dana, seiring berjalannya waktu kegunaan Bank menjadi meluas dan menjadi sumber transaksi pendanaan yang dapat membantu masyarakat mengembangkan ide - idenya untuk berkembang dengan menggunakan berbagai cara atau produk yang di tawarkan setiap Bank. Cara atau produk yang paling sering digunakan Bank untuk menarik minat para Karyawannya ialah menawarkan kredit pinjaman, baik kredit pinjaman tunai ataupun pinjaman KPR yang merupakan kredit atas pembelian rumah. Bisnis Perbankan ini dijalankan dengan sistem kepercayaan sehingga kesuksesan badan usaha perbankan sangatlah bergantung pada tingkat kepuasan atas Karyawan yang telah mempercayakan Bank tersebut dalam menghimpun harta mereka.

Seperti yang dikemukakan di dalam buku Arasli (2005:35) yang menyebutkan bahwa Bank memahami bahwa penyampaian kualitas jasa pada pelanggan adalah perlu sekali agar sukses dan dapat bertahan dalam keadaan global dan dalam lingkungan perbankkan yang kompetitif pada masa sekarang ini. Banyak cara yang dilakukan oleh pihak Bank untuk dapat memberikan kepuasan kepada para Karyawannya. Salah satu cara umum yang mereka tunjukan yaitu dengan memberikan pelayanan secara tanggap, cepat dan ramah, baik terhadap Karyawan mereka ataupun calon Karyawan yang berminat untuk bergabung menjadi salah satu anggota Karyawan Bank tersebut.

Perkembangan dunia perbankan saat ini sangatlah pesat dimana banyaknya bisnis perbankan yang ada membuat persaingan antar Bank semakin ketat, maka dari itu Bank banyak melakukan inovasi - inovasi dalam melakukan pengembangan produk - produk yang mereka tawarkan untuk menarik minat para masyarakat sebagai Karyawan mereka.

Berdasarkan pengertian Bank yang tercantum dalam pasal 1 ayat (2) Undang - Undang No. 10 Tahun 1998 tentang perbankan yang merumuskan pengertian Bank ialah badan usaha yang menghimpun dana dari masyarakat dalam bentuk simpanan dan menyalurkannya kepada masyarakat dalam bentuk kredit dan atau bentuk - bentuk lainnya dalam rangka meningkatkan taraf hidup rakyat banyak. Bank tidak hanya bertugas untuk menghimpun dana dari masyarakat luas tetapi Bank merupakan alat pembantu atas pembangunan perekonomian nasional suatu negara dimana Bank bertugas untuk menjadi alternatif sumber pendanaan atas investasi baik perorangan maupun organisasi. Dimana Bank menyalurkan dananya untuk dapat membantu para investor baik kecil menengah atau besar sekalipun yang ingin mengembangkan bisnisnya.

Beberapa perbankan di Indonesia mempunyai berbagai macam Sistem Akuntansi yang berbeda. Dapat disimpulkan bahwa Sistem Akuntansi adalah metode dan prosedur untuk mencatat dan melaporkan informasi keuangan yang disediakan bagi perusahaan. Sistem Akuntansi membutuhkan suatu proses penyusunan laporan selanjutnya yang akan digunakan sebagai alat komunikasi untuk keperluan manajemen, baik intern perusahaan maupun keperluan ekstern perusahaan. Pihak intern perusahaan memanfaatkan Sistem Akuntansi beserta hasilk hasilnya sebagai sarana manajemen dibidang perencanaan dan pengendalian, sedangkan pihak ekstern perusahaan yang memiliki kepentingan umum meminta pertanggung jawaban perusahaan dalam bentuk laporan keuangan yang merupakan Sistem Akuntansi.

Sistem Akuntansi memanfaatkan sumber daya yang ada dalam perusahan. Sumber daya karyawan, mesin otomatis, komputer maupun sumber daya lainnya.

Sistem Akuntansi dapat dilaksanakan secara manual (dengan memanfaatkan tenaga karyawan ataupun mesin otomatis, misalnya mesin fotocopi, kalkulator, mesin tik) atau dengan komputerisasi (dengan menggunakan komputer).

Didalam dunia perbankan Sistem Akuntansi sangat diperlukan untuk menjalankan suatu proses transaksi. Adapun juga dalam pemberian kredit yang diberikan kepada Karyawan maupun sistem dalam Pengendalian Internal didalam suatu perbankan itu sendiri.Pengendalian Internal merupakan suatu cara untuk mengarahkan, mengawasi, dan mengukur sistem daya suatu organisasi dalam pemberian kredit.

Pengendalian Internal yang memadai pada dasarnya bertujuan utnuk melindungi harta milik organisasi dengan meminimalkan kemungkinan terjadinya penyelewengan, pemborosan, 
kredit macet, serta meningkatkan efesiensi dan efektivitas kerja dengan Pengendalian Internal yang baik.

Boynton dkk (2003) dalam Amanina (2010:28) mengungkapkan pentingnya Pengendalian Internal adalah sebagai berikut: (a) Lingkup dan ukuran bisnis entitas telah menjadi sangat kompleks dan tersebar luas sehingga manajemen harus bergantung pada sejumlah laporan dan analisis untuk mengendalikan operasi secara efektif. (b) Pengujian dan penelaah yang melekat dalam sistem Pengendalian Internal yang baik menyediakan perlindungan terhadap kelemahaan manusia dan mengurangi kemungkinan terjadinya kekeliruan dan ketidak beresan. (c) Tidak praktis bagi auditor untuk melalukan audit atas kebanyakan perusahaan dengan pembatasaan biaya ekonomi tanpa menguntungkan pada sistem Pengendalian Internal.

Bank merupakan salah satu sumber permodalan yang sangat dibutuhkan oleh masyarakat dalam menjalankan kegiatan usahanya. Sehingga Bank dituntut peran sertanya untuk mensukseskan pembangunan melalui jasa kredit yang sangat dibutuhkan masyarakat. Pemberian kredit sangat berguna bagi masyarakat karena dapat mendorong pertumbuhan perekonomian suatu bangsa. Namun, pengelolaan perkreditan mempunyai berbagai masalah yang cukup rumit seperti timbulnya kredit macet, yang disebabkan karena tidak mampunya Karyawan dalam memenuhi kewajibanya.

Menurut Veithzal (2007:4) dalam bukunya yang berjudul credit management handbook, kredit adalah penyerahan barang, jasa atau uang dari suatu pihak ( kreditur/ pemberi kredit) atas dasar kepercayaan kepada pihak lain (Karyawan atau borrower) dengan janji membayar dari penerima kredit kepada poemberi kredit dengan tanggal yang telah disepakati kedua belah pihak. Menurut Undang - Undang Perbankan Nomor 10 Tahun 1998 sebagaimana dikutip oleh Kasmir (2011:96) kredit adalah penyediaan uang dan tagihan yang dapat dipersamakan dengan itu, berdasarkan persetujuan atau kesepakatan pinjam meminjam antara Bank dengan pihak lain yang mewajibkan pihak peminjam melunasi utangnya setelah jangka waktu tertentu dengan pemberian bunga.

Pemberian kredit memiliki sebuah resiko yaitu adanya kredit macet. Bahaya yang timbul dari kredit macet adalah tidak terbayarnya kembali kredit tersebut, baik sebagian maupun seluruhnya. Kredit macet terjadi sebagai akibat analisis pemberian persetujuan kredit yang tidak begitu ketat. Kredit macet memberikan dampak yang kurang baik bagi negara, masyarakat, dan perbankan indonesia. Likuiditas, Solvabilitas, Profabilitas Bank sangat dipengaruhi oleh keberhasilan Bank dalam mengelola kredit yang disalurkan.

Kredit macet dalam jumlah besar dapat berpengaruh terhadap Bank tersebut. Untuk menghasilkan yang baik diperlukan pengelolaan perkreditan yang baik dengan penerapan Pengendalian Internal yang efektis dan efesien. Didalam pemberian kredit harus mempunyai sistem Pengendalian Internal yang baik juga. Pengendalian Internal atau kontrol internal didefinisikan sebagai suatu proses yang dipengaruhi oleh sumber daya manusia dan sistem teknologi informasi yang dirancang untuk membantu organisasi atau suatu perusahaan mencapai suatu tujuan atau objektif tertentu. Pengendalian Internal merupakan suatu cara untuk mengarahkan, mengawasi, dan mengukur sistem daya suatu organisasi dalam pemberian kredit

PT Bank OCBC NISP Tbk mempunyai beberapa produk - produk perkreditan yang ditawarkan dimana ini sangat mendukung akan keberadaannya di kota Batam sebagai penunjang suatu usaha maupun membantu perekonomian masyarakat di kota Batam. Berdasarkan hal tersebut saya sebagai penulis tertarik untuk menelaah lebih lanjut tentang "Pengaruh Sistem Akuntansi dan Pengendalian Internal Terhadap Pemberian Kredit Oleh PT Bank OCBC NISP Tbk Kota Batam".

Berdasarkan penjabaran diatas maka rumusan masalah adalah Seberapa besar Pengaruh Sistem Akuntansi Dan Pengendalian Internal Terhadap Pemberian Kredit Pada PT Bank OCBC NISP Tbk Kota Batam baik secara pasrsial maupun secara simultan. Tujuan penelitian adalah Untuk mengetahui Pengaruh Sistem Akuntansi Dan Pengendalian Internal Terhadap Pemberian 
Kredit Pada PT Bank OCBC NISP Tbk Kota Batam. baik secara pasrsial maupun secara simultan.

\section{TINJAUAN PUSTAKA}

\section{A. Sistem Akuntansi}

Peran Sistem Akuntansi dalam kegiatan perusahaan ini sangat penting. Para pemimpin membutuhkan informasi yang diperlukan terutama berupa informasi keuangan yang berguna untuk pengambilan keputusan. Keputusan yang diambil harus tepat agar dapat mengantisipasi perkembangan usaha dan menyelesaikan berbagai masalah, untuk itu diperlukan informasi yang tepat waktu dan dapat diandalkan. Untuk memenuhi kebutuhan akan informasi yang bersifat terus-menerus maka informasi tersebut perlu diorganisisr dengan diselenggarakannya suatu perangkat yang disebut Sistem Akuntansi.

Suatu Sistem Akuntansi diperlukan untuk memudahkan pengelolaan perusahaan. Menurut Narko (2007:3) pengertian Sistem Akuntansi adalah jaringan yang terdiri dari formuli formulir, catatan - catatan, prosedur - prosedur, alat - alat, dan sumber daya manusia dalam rangka menghasilkan informaasi pada suatu organisasi untuk keperluan pengawasan, operasi, maupun untuk kepentingan pengambilan keputusan bisnis bagi pihak - pihak yang berkepentingan. Jadi dapat ditarik kesimpulan bahwa Sistem Akuntansi terdiri dari beberapa unsur akuntansi meliputi organisasi, formulir, catatan, dan laporan yang saling terkait untuk mencapai tujuan, yaitu menyediakan informasi keuangan yang dibutuhkan oleh pengguna yang berwenang khususnya manajemen dalam mengelola perusahaan menjadi lebih efektif, efesien, dan ekonomis.

Perancang dan pemakai sistem perlu memahami komponen - komponen yang ada di dalam suatu sistem informasi, agar dapat menjaga kelancaran berfungsinya sistem dan mendapat manfaat yang maksimum dari sistem yang dimilikinya. Apabila ada gangguan terhadap sistem, perancang, pengelola, atau pemakai sistem dapat mengambil tindakan seperlunya untuk mengembalikan sistem ke fungsinya semula. Sistem informasi bukanlah merupakan suatu benda yang pasif, tetapi akan terus bergerak dalam bentuk proses, sehingga dapat terjadi perubahan. Pengaruh sistem informasi bagi perusahaan, sistem akuntansi yang dibangun dan digunakan oleh perusahaan, akan member pengaruh proses kegiatan didalam perusahaan. Dalam sistem akuntansi yang masih manual, proses yang rumit (misalnya pemesanan pembelian barang secara kredit) akan memerlukan waktu yang relative lama, karna petugas yang satu akan mengerjakan pekerjaannya, sebelum diproses oleh karyawan berikutnya. Apabila dikerjakan dengan komputer akan memerlukan waktu lebih singkat dan keakuratan data lebih terjamin.

Dengan kata lain Sistem Akuntansi harus dirancang untuk memastikan perihal kejadian, kelengkapan, keakuratan, posting dan pengikhtisaran, klasifikasi, dan penetapan waktu transaksi dicatat. Menurut Warren, Reeve, Fees yang diterjemahkan oleh Aria Farahwati dalam bukunya Warren, Reeve, Fees (2005: 234), Sistem Akuntansi adalah metode dan prosedur yang mengumpulkan, mengklasifikasikan, mengikhtisarkan, dan melaporkan informasi operasi dan keuangan sebuah perusahaan.

\section{B. Pengendalian Internal}

Suatu perusahaan menyusun sistem Pengendalian Internal dalam rangka untuk membantu dalam proses pencapaian tujuannya. Manajemen dalam menjalankan fungsinya membutuhkan sistem pengendalian yang dapat mengamankan harta perusahaan, memberikan keyakinan bahwa apa yang dilaporkan adalah benar - benar dapat dipercaya dan dapat mendorong adanya 
efesiensi usaha serta dapat terus menerus memantau bahwa kebijakansanaan yang telah diterapkan memang dijadikan sesuai dengan apa yang diharapkan.

Menurut Ikatan Akuntansi Indonesia (2007:39) Pengendalian Internal adalah sistem yang meliputi organisasi semua metode dan ketentuan yang terorganiasi yang dianut dalam suatu perusahaan untuk melindungi harta miliknya, mencek kecermatan dan keandalan data akuntansi serta meningkatkan efisiensi usaha. Menurut Drs. Amin Widjaja Tunggal (2010:195) Pengendalian Internal adalah suatu proses yang dijalankan oleh dewan komisaris, manajemen, personalia entitas lain yang didisain untuk memberikan keyakinan memadai tentang pencapaian tiga golongan tujuan berikut ini: (a) Keandalan pelaporan keuangan (b) Efektivitas dan efesiensi operasi dan (c) Kepatuhan terhadap hukum dan peraturan yang berlaku. Sedangkan menurut Krismaji (2010:218) Pengendalian Internal (Internal Control) adalah rencana organisasi dan metode yang digunakan untuk menjaga atau melindungi aktiva, menghasilkan informasi yang akurat dan dapat dipercaya.meliputi struktur organisasi, metode dan ukuran - ukuran yang dikoordinasika untuk menjaga kekayaan organisasi, mengecek ketelitian dan kendalan data akuntansi, mendorong efesiensi dan mendorong dipatuhinya kebijakan manajemen.

Dapat ditarik kesimpulan dari definisi beberapa ahli bahwa Pengendalian Internal adalah suatu proses dalam bentuk rencana organisasi dan metode yang digunakan atau melindungi aktiva, dan menghasilkan informasi yang akurat dan dapat dipercaya, yang dijalankan oleh Dewan komisaris, Manajemen, Personel lain entitas.

\section{Pemberian Kredit}

Suyatno (2005:13) mengatakan bahwa istilah kredit berasal dari bahasa Yunani, credere yang berarti kepercayaan atau truth atau faith. Dalam hal ini yang berarti suatu kebenaran atau kepercayaan dimana seseorang memerlukan bantuan dalam bentuk permodalan dalam meningkatkan tingkat ekonomi seseorang dan ingin mengajukan suatu bentuk pernyataan pinjaman bantuan dari Bank maupun lembaga keuangan bukan Bank dalam bentuk tambahan modal inilah yang sering disebut dengan kredit.

Kredit dalam arti luas menurut Mulyono (2007:9) ialah kemampuan untuk melaksanakan suatu pembelian dan mengadakan suatu pinjaman dengan suatu janji pembayaran yang dilakukan pada suatu jangka waktu yang disepakati.

Menurut Subagyo (2006:42) pengertian kredit adalah suatu aktivitas dengan penyerahan barang, jasa atau uang dari satu pihak (kreditor atau pemberi pinjaman) atas dasar kepercayaan kepada pihak lain (Karyawan) dengan janji membayar dari penerima kredit kepada pemberi kredit pada tanggal yang telah disepakati kedua belah pihak.

Pengertian kredit menurut Firdaus \& Ariyanti (2009:5) dalam manajemen pengkreditan adalah pengelolaan kredit yang dijalankan oleh bank meliputi perencanaan, pengorganisasian, pelaksanaan, pengawasan sedemikian rupa sehingga kredit tersebut berjalan dengan baik sesuai dengan kesepakatan antara bank dengan debitur.

Sudirman (2013:45) menyatakan bahwa dalam penyediaan uang atau dana oleh bank berdasarkan persetujuan atau kesepakatan pinjam meminjam antara bank dengan pihak lain dan mewajibkan pihak lain untuk melunasi utang setelah jangka waktu tertentu dengan pemberian bunga, imbalan atau pembagian hasil usaha disebut kredit.

Simorangkir (2005:2) mengatakan kredit adalah pemberian prestasi (misalnya uang atau barang) dengan balas prestasi (kontra prestasi) yang terjadi pada waktu yang akan datang. Kehidupan ekonomi modern adalah prestasi uang yang demikian transaksi kredit menyangkut uang sebagai alat kredit. 
Kasmir (2005:94) mengatakan kredit yang diberikan oleh suatu lembaga kredit didasarkan atas kepercayaan, sehingga dengan demikian Pemberian Kredit merupakan pemberian kepercayaan. Hal itu berarti suatu lembaga kredit baru akan memberikan kredit kalau betul-betul yakin bahwa si penerima kredit akan mengembalikan pinjaman yang telah diterimanya sesuai dengan jangka waktu dan syarat - syarat yang telah disetujui bersama.

Dengan demikian dapat disimpulkan bahwa unsur - unsur kredit adalah sebagai berikut:

1. Kepercayaan

Yaitu adanya keyakinan dari pihak bank atas prestasi yang diberikannya kepada Karyawan peminjam dana yang akan dilunasinya sesuai dengan diperjanjikan pada waktu tertentu,

2. Tenggang waktu

Yaitu adanya jangka waktu tertentu antara Pemberian Kredit dan pelunasannya, jangka waktu tersebut sebelumnya terlebih dahulu disetujui atau disepakati bersama antara pihak bank dan Karyawan peminjam dana.

3. Prestasi

Yaitu adanya obyek tertentu berupa prestasi pada saat tercapainya persetujuan atau kesepakatan perjanjian Pemberian Kredit antara bank dengan Karyawan peminjam dana berupa uang dan bunga atau imbalan.

4. Risiko

Yaitu adanya risiko yang mungkin terjadi selama jangka waktu antara pemberian dan pelunasan kredit tersebut sehingga untuk mengamankan Pemberian Kredit dan menutup kemungkinan terjadinya wanprestasi dari Karyawan peminjam dana, maka diadakanlah pengikatan jaminan dan agunan.

Hartono (2005:33) menyatakan jika strategi perusahaan perlu dibentuk di dalam perusahaan. Istilah mengukir strategi mempunyai arti yang lebih mendalam dibandingkan sekedar hanya memilih strategi. Pengukiran strategi tidak hanya memilih strategi saja, tetapi strategi harus di ukir, yaitu strategi harus dipilih sedemikian rupa sehingga cocok, tepat dan pas di dalam organisasi supaya dapat terbentuk rapi dan sesuai dan dapat dengan mudah mencapai tujuan yang dituju.

Kasmir (2008: 95) menyatakan tujuan prosedur Pemberian Kredit adalah untuk memastikan kelayakan suatu kredit, diterima atau ditolak. Dalam menentukan kelayakan suatu kredit maka dalam setiap tahap selalu dilakukan penilaian yang mendalam. apabila dalam penilaian mungkin ada kekurangan maka pihak bank dapat meminta kembali ke Karyawan atau bahkan langsung menolak permintaan kredit yang telah diajukan.

Pihak bank harus mengadakan kunjungan atau survey ke debitur untuk mendapatkan data atau informasi yang lebih detail dan terinci serta mencari tambahan informasi yang berkaitan dengan permohonan kredit. Data-data tersebut meliputi 6C yaitu character, capacity, capital, collateral, condition dan compliance dari debitur. Kemudian data tersebut dianalisa untuk mengetahui serta menentukan kesanggupan dan kesungguhan debitur dalam membayar kembali pinjaman sesuai dengan persyaratan yang terdapat dalam perjanjian kredit. Petugas kredit akan menganalisa permohonan kredit tersebut berdasarkan analisis berbasis 6C, serta aspek-aspek lainnya dalam penilaian kredit. Hal tersebut didasarkan pada tujuan analisis kredit yaitu menyelidiki dengan baik secara kuantitatif dan kualitatif calon Karyawan dan menentukan besar dan jenis kredit, kemauan dan kemampuan Karyawan untuk mengembalikan pinjaman tepat waktu. 
Berdasarkan kajian teori di atas, kerangka berpikir dalam penelitian ini yang berjudul Pengaruh Sistem Akuntansi Dan Pengendalian Internal Terhadap Pemberian Kredit Pada PT Bank OCBC NISP Tbk Kota Batam. Untuk mempermudah dalam penelitian, peneliti menyusun bagan alur kerangka pemikiran sebagai berikut:

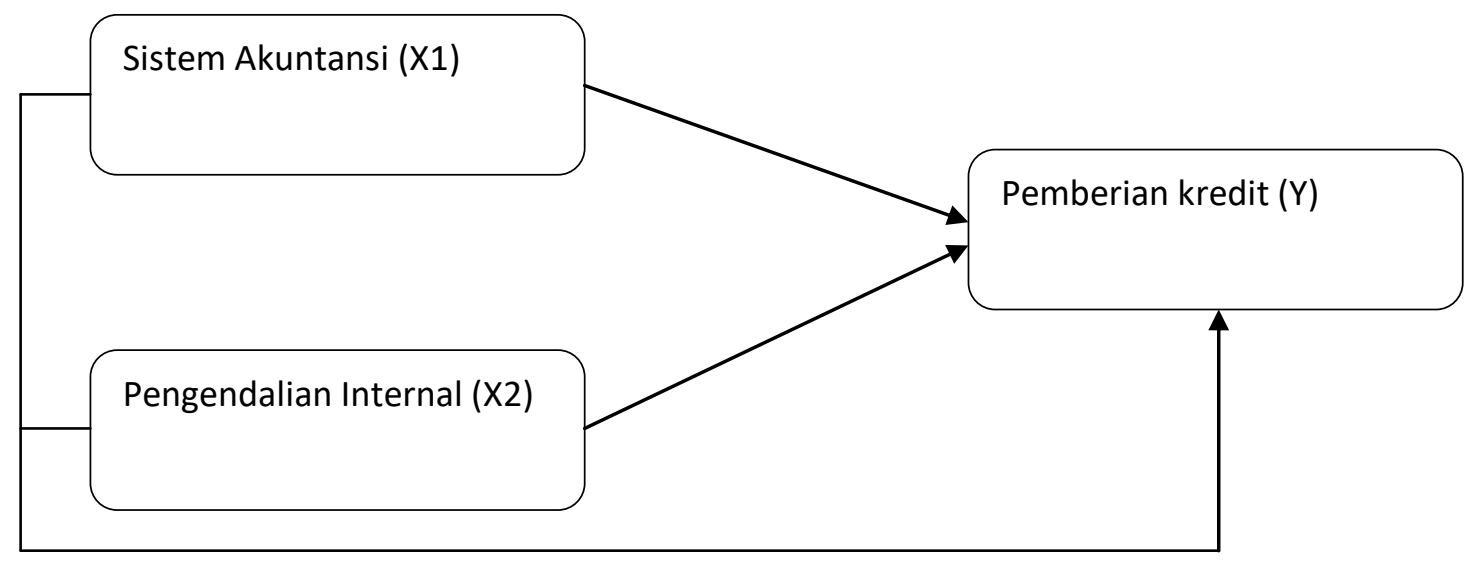

Gambar 1. Kerangka berfikir penelitian

Dari kerangka pemikiran yang telah di jelaskan pada sub bab sebelumnya yang menjurus pada hipotesis dapat disimpulkan bahwa hipotesis yang di dapat ialah sebagai berikut:

H1: Sistem Akuntansi berpengaruh signifikan terhadap Pemberian Kredit oleh PT. Bank OCBC NISP Tbk Kota Batam.

H2: Variabel Pengendalian Internal berpengaruh signifikan terhadap Pemberian Kredit oleh PT. Bank OCBC NISP Tbk Kota Batam.

H3: Variabel Sistem Akuntansi dan Pengendalian Internal berpengaruh signifikan terhadap Pemberian Kredit oleh PT. Bank OCBC NISP Tbk Kota Batam.

\section{METODE}

Efferin (2012:48) mengemukakan bahwa desain penelitian (research design), adalah merupakan framework dari suatu penelitian ilmiah. Desain penelitian yang baik akan menjadi menentukkan keberhasilan serta kualitas dari suatu penelitian ilmiah. Dengan menyusun suatu desain penelitian, peneliti pada dasarnya membuat arahan tentang berbagai hal yang harus dilakukan dalam upaya untuk melakukan suatu penelitian.

Penelitian ini verifikatif untuk melihat hubungan dan pengaruh antar variabel, yaitu pengaruh antara variabel indenpenden Sistem Akuntansi $\left(X_{1}\right)$ dan Pengendalian Internal $\left(X_{2}\right)$ terhadap variabel dependen Pemberian Kredit (Y). Objek penelitian adalah Karyawan PT Bank OCBC NISP Tbk Kota Batam, unit analisis Karyawan PT Bank OCBC NISP Tbk Kota Batam.

Metode penelitian ini menggunakan metode verifikatif atau kausalitas. Populasinya berjumlah 151 Orang dengan sampel 151 orang. Objek Penelitian PT Bank OCBC NISP Tbk Kota Batam dengan unit analisis Karyawan PT Bank OCBC NISP Tbk Kota Batam. Data di peroleh dengan menggunakan kuesioner dan menginterview staf dan pimpinan PT Bank OCBC NISP Tbk Kota Batam. 


\section{HASIL DAN PEMBAHASAN}

\section{A. Hasil Pengujian Hipotesis}

Pengujian hipotesis dalam penelitian ini dilakukan dengan menggunakan uji statistik $t$, uji statistik F

\section{Hasil Uji T}

Uji Statistik t digunakan untuk mengetahui ada atau tidaknya pengaruh masing-masing variabel independen secara parsial terhadap variabel dependen yang diuji pada tingkat signifikansi 0,05. Hasil uji t dalam penelitian ini ditunjukkan dalam tabel 1 dibawah ini.

Tabel 1. Hasil Uji T

Coefficients $^{\mathrm{a}}$

\begin{tabular}{|rl|r|r|r|r|r|}
\hline \multirow{2}{*}{ Model } & \multicolumn{2}{|c|}{$\begin{array}{c}\text { Unstandardized } \\
\text { Coefficients }\end{array}$} & $\begin{array}{c}\text { Standardized } \\
\text { Coefficients }\end{array}$ & \multicolumn{1}{c|}{ t } & \multicolumn{1}{c|}{} \\
\cline { 3 - 5 } & \multicolumn{1}{|c|}{ B } & Std. Error & \multicolumn{1}{c|}{ Beta } & & \\
\hline \multirow{2}{*}{1} & (Constant) & 4.236 & 1.060 & & $\mathbf{3 . 9 9 6}$ & $\mathbf{. 0 0 0}$ \\
& X1 & .944 & .126 & .522 & $\mathbf{7 . 4 6 9}$ & $\mathbf{. 0 0 0}$ \\
& X2 & .341 & .054 & .443 & $\mathbf{6 . 3 3 9}$ & $\mathbf{. 0 0 0}$ \\
\hline
\end{tabular}

a. Dependent Variable: Y

\section{1) Hipotesis Penelitian Pertama}

Hasil dari Tabel 1 di atas menunjukkan bahwa $\mathrm{T}_{\text {hitung }}$ yang diperoleh untuk variabel Sistem Akuntansi $\left(\mathrm{X}_{1}\right)$ sebesar $\mathbf{7 . 4 6 9}$ dan signifikan sebesar 0,000. Hal ini menunjukkan $\mathrm{T}_{\text {hitung }}=$ 7.469 $>\mathrm{T}_{\text {Tabel }}=\mathbf{1 . 6 5 5 2 1}$ atau signifikan kecil dari 0,05, maka Hipotesis Pertama dalam penelitian ini diterima yaitu Sistem Akuntansi $\left(\mathrm{X}_{1}\right)$ berpengaruh secara signifikan terhadap Pemberian Kredit (Y) pada PT Bank OCBC NISP Tbk di Kota Batam.

\section{2) Hipotesis Penelitian Kedua}

Dan $T_{\text {hitung }}$ yang diperoleh untuk variabel Pengendalian Internal $\left(X_{2}\right)$ sebesar 6.339 dan signifikan sebesar 0,000 . Hal ini menunjukkan $\mathrm{T}_{\text {hitung }}=\mathbf{6 . 3 3 9}>\mathrm{T}_{\text {Tabel }}=\mathbf{1 . 6 5 5 2 1}$ atau signifikan kecil dari 0,05, maka Hipotesis Kedua dalam penelitian ini diterima yaitu Pengendalian Internal $\left(\mathrm{X}_{2}\right)$ berpengaruh secara signifikan terhadap Pemberian Kredit $(\mathrm{Y})$ pada PT Bank OCBC NISP Tbk di Kota Batam.

\section{Hasil Uji F}

Uji statistik $F$ digunakan untuk mengetahui apakah semua variabel bebas yang dimasukkan dalam model mempunyai pengaruh secara simultan terhadap variabel terikat. Berikut ini hasil uji statistik F dapat ditunjukan pada tabel 2.

Tabel 2. Hasil Uji F

ANOVA $^{\mathrm{a}}$

\begin{tabular}{|rl|r|r|r|r|l|}
\hline Model & & \multicolumn{1}{c|}{ Sum of } & \multicolumn{1}{c|}{ Df } & Mean Square & F & \multicolumn{1}{l|}{ Sig. } \\
& & Squares & & & & \\
\hline \multirow{3}{*}{1} & Regression & 11573.209 & 2 & 5786.605 & $\mathbf{6 5 9 . 4 5 0}$ & $\mathbf{. 0 0 0}^{\mathbf{b}}$ \\
& Residual & 1298.685 & 148 & 8.775 & & \\
& Total & 12871.894 & 150 & & & \\
\hline
\end{tabular}

a. Dependent Variable: Y

b. Predictors: (Constant), X1, X2

Sesuai dari Tabel 6 diatas menunjukkan bahwa $F_{\text {hitung }}=\mathbf{6 5 9 . 4 5 0 9}>\mathrm{F}_{\text {Tabel }}=\mathbf{3 . 0 6}$ (lihat pada Tabel distribusi F) dan signifikan $=0,000<0,05$, maka Hipotesis Ketiga dalam penelitian 
ini diterima yaitu Sistem Akuntansi $\left(\mathrm{X}_{1}\right)$ dan Pengendalian Internal $\left(\mathrm{X}_{2}\right)$ berpengaruh secara signifikan terhadap Pemberian Kredit(Y) pada PT Bank OCBC NISP Tbk di Kota Batam

\section{SIMPULAN}

Penelitian ini ingin menguji Sistem Akuntansi dan Pengendalian Internal berpengaruh secara signifikan terhadap Pemberian Kredit pada PT Bank OCBC NISP Tbk Kota Batam. Adapun beberapa kesimpulan penelitian ini adalah sebagai berikut:

1. Berdasarkan pengujian hipotesis pertama ditemukan bahwa variabel Sistem Akuntansi mempunyai pengaruh yang signifikan terhadap Pemberian Kredit pada PT Bank OCBC NISP Tbk Kota Batam.

2. Pengujian hipotesis kedua ini berhasil membuktikan adanya pengaruh yang signifikan Pengendalian Internal terhadap Pemberian Kredit pada PT Bank OCBC NISP Tbk Kota Batam.

3. Hasil penelitian ini membuktikan bahwa Sistem Akuntansi, dan Pengendalian Internal secara simultan berpengaruh signifikan terhadap Pemberian Kredit pada PT Bank OCBC NISP Tbk Kota Batam.

\section{SARAN}

PenurunanTingkat Pemberian Kredit dapat ditingkatkan di PT Bank OCBC NISP Tbk di Kota Batam dengan Sistem Akuntansi yang lebih baik, maka untuk memacu manajemen dalam penerapan maka dalam penelitian ini penulis berikan saran sebagai berikut:

1. Dokumen yang digunakan dalam sistem pemberian kredit seperti sebaiknya diberi nomor urut cetak. Hal ini perlu dilakukan untuk mengawasi pemakaiannya dan untuk memudahkan identifikasi dan pencarian kembali dokumen yang diperlukan.

2. Disarankan kepada pihak PT Bank OCBC NISP Tbk di Kota Batam terutama pihak yang bertugas memberikan kredit lebih memaksimalkan lagi penerapan sistem pengendalian intern dengan cara melakukan pemeriksaaan dan pemantauan terhadap proses pemberian kredit sesering mungkin, sehingga jika terjadi masalah dapat diketahui sejak dini. selain itu bagian perkreditan perlu menetapkan kriteria-kriteria tertentu guna mencapai tujuan pemberian kredit. Kriteria-kriteria seperti 5C, yaitu character, capacity, capital, coolateral dan condition of economic tetap relevan.

3. Sebaiknya PT Bank OCBC NISP Tbk di Kota Batam harus lebih memperhatikan efektivitas pengendalian internal agar Sistem Akuntansi yang dihasilkan lebih efektif dan efisien. Karena apabila efektivitas pengendalian internal yang baik dapat menunjang Sistem Akuntansi yang lebih baik lagi, keduanya berhubungan sangat erat.

4. Untuk penelitian selanjutnya, maka perlu dilakukan penelitian lebih lanjut, faktor apa saja yang mempengaruhi Pemberian Kredits elain Sistem Akuntansi dan Pengendalian Internal.

\section{DAFTAR PUSTAKA}

Dendawijaya, Lukman. (2009). Manajemen Perbankan, Edisi Kedua, Cetakan Kedua, Ghalia Indonesia, Bogor Jakarta.

Elder, Mark S. Beasley. (2010). Auditing dan Jasa Assurance,. Edisi 12, Penerbit Erlangga, Jakarta.

Fees, Reeve dan Warren. (2005). Pengantar Akuntansi, Edisi 21, Penerbit Salemba. Empat, Jakarta.

Fakhri, Husein. (2004). Sistem Pengendalian Manajemen. Jakarta: PT. Gramedia Pustaka Utama.

Firdaus dan Ariyanti. (2009). Manajemen Perkreditan Bank Umum, Bandung: Alfabeta.

Faisal, Abdullah. (2005). Manajemen Perbankan: Teknik Analisis Kinerja Keuangan Bank. Malang: Universitas Muhammadiyah. 
Hasibuan, Malayu S.P. (2006). Manajemen Dasar, Pengertian, dan. Masalah, Edisi Revisi, Bumi Aksara: Jakarta.

Ikatan Akuntan Indonesia. (2007). Standar Akuntansi Keuangan. Edisi 2007. Penerbit: Salemba Empat. Jakarta.

Jones, Frederick L. dan Rama, Dasaratha V. (2008). Sistem Informasi Akuntansi. Terjemahkan Wibowo., Salemba empat, Jakarta.

Kasmir. (2011). Bank dan Lembaga Keuangan Lainnya. Jakarta: PT. Raja. Grafindo Persada.

Krismiaji. (2005). Sistem Informasi Akuntansi, Edisi Kedua; Yogyakarta : Akademi Manajemen. Perusahaan YKPN.

Pasal 1 Ayat (2) Undang - Undang No. 10 Tahun 1998 Tentang Perbankan.

Susanto, Azhar. (2007). Sistem Informasi Akuntansi. Jakarta: T. Lingga Jaya.

Sudirman, Indrianty. (2013). Mengupas Tuntas Kredit Komersial dan Konsuntif dalam Perjanjian Kredit. Alfabeta. Bandung.

Simorangkir. (2005). Pengantar Lembaga Keungan Bank dan Non Bank. Jakarta: Ghalia Indonesia.

Sugiyono. (2013). Metode Penelitian Pendekatan Kuantitatif kualitatif Dan $R \& D$, cetakan kesembilan belas. Bandung: Alfa Beta.

Suyatno, Thomas. (2005). Kelembagaan Perbankan, Jakarta : PT. Gramedia Pustaka Utama. Subagyo. (2006). Studi Kelayakan Teori dan Aplikasi. Jakarta: PT. Elex Media Komputindo. Tunggal, Amin Widjaja. (2010). Akuntansi Manajemen, Harvindo, Jakarta.

Murtanto. (2005). Sistem Pengendalian Internal Kas, PT. Hecca Mitra Utama,. Jakarta.

Mulyadi. (2010). Auditing. Edisi Keenam. Buku 1. Jakarta: Salemba Empat.

Mulyono, Teguh Pudjo. (2007). Manajemen Perkreditan Bagi Perbankan. Komersil . Yogyakarta: BPFE.

Martono, Nanang. (2010). Metode Penelitian Kuantitatif (Analisis Isi dan Analisis Data Sekunder) Edisi Revisi. PT. Raja Grafindo Persada. Jakarta.

Marbun, Anderson. (2006). Program Studi Akuntansi Universitas Widyatama. Peranan Pengendalian Internal Dalam Menunjang Sistem Pemberian Kredit Usaha Kecil dan Menengah dengan studi kasus Koperasi simpan pinjam Artha Jaya Sentosa Jakarta.

Narko. (2007). Sistem Akuntansi, Penerbit Yayasan Pustaka Nusatama.

Undang - Undang Republik Indonesia tentang Perbankan No. 7 Tahun 1992

Undang - Undang Perbankan Nomor 10 Tahun 1998.

Veithzal, Rivai. (2007). Bank and Financial Institute Management. Jakarta: PT. Raja Grafindo Persada. 